Article

\title{
Dust Climatology of the NASA Dryden Flight Research Center (DFRC) in Lancaster, California, USA
}

\author{
Ashok K. Pokharel ${ }^{1,2, *}$ and Michael L. Kaplan ${ }^{2}$ \\ 1 Graduate Program in Atmospheric Sciences, University of Nevada, Reno, NV 89557, USA \\ 2 Division of Atmospheric Sciences, Desert Research Institute, Reno, NV 89512, USA; Michael.Kaplan@dri.edu \\ * Correspondence: ashokpokharel@hotmail.com; Tel.: +1-775-250-2853
}

Academic Editors: Jiwen Fan and Yang Zhang

Received: 15 December 2016; Accepted: 21 February 2017; Published: 25 February 2017

\begin{abstract}
A 15-year (1997-2011) climatology of dust events at the NASA DFRC in Lancaster, California, USA, was performed to evaluate how the extratropical systems were associated with dust storms over this region. For this study, we collected meteorological data for Edwards Air Force Base (EAFB) in Lancaster, California, which is very close to NASA DFRC, from wunderground.com, National Centers for Environmental Prediction (NCEP)/North American Regional Reanalysis (NARR), NCEP/Hydro-meteorological Prediction Center/National Weather Service (NWS), and Unisys analyses. We find that the dust events were associated with the development of a deep convective boundary layer, turbulence kinetic energy (TKE) $\geq 3 \mathrm{~J} / \mathrm{kg}$, a deep unstable lapse rate layer, a wind speed above the frictional threshold wind speed necessary to ablate dust from the surface $(\geq 7.3 \mathrm{~m} / \mathrm{s})$, a presence of a cold trough above the deep planetary boundary layer (PBL), a strong cyclonic jet, an influx of vertical sensible heat from the surrounding area, and a low volumetric soil moisture fraction $<0.3$. The annual mean number of dust events, their mean duration, and the unit duration per number of event for each visibility range, when binned as $<11.2 \mathrm{~km},<8 \mathrm{~km}$, $<4.8 \mathrm{~km},<1.6 \mathrm{~km}$, and $<1 \mathrm{~km}$ were calculated. The visibility range values were positively correlated with the annual mean number of dust events, duration of dust events, and the ratio of duration of dust events. The percentage of the dust events by season shows that most of the dust events occurred in autumn $(44.7 \%)$, followed by spring $(38.3 \%)$, and equally in summer and winter with these seasons each accounting for $8.5 \%$ of events. This study also shows that the summer had the highest percentage $(10 \%)$ of the lowest visibility condition $(<1 \mathrm{~km})$ followed by autumn $(2 \%)$. Neither of the other two seasons-winter and spring-experienced such a low visibility condition during the entire dust events over 15 years. Winter had the highest visibility $(<11.2 \mathrm{~km})$ percentage, which was $67 \%$ followed by spring $(55 \%)$. Wind speed increasing to a value within the range of $3.6-11 \mathrm{~m} / \mathrm{s}$ was typically associated with the dust events.
\end{abstract}

Keywords: climatology; dust events; frequency; visibility; wind rose; TKE; cyclonic jet

\section{Introduction}

Wind erosion produces dust that can cause environmental impacts at regional and global scales [1-3]. Tegen and Fung [4] estimated about $3000 \mathrm{Mt} \cdot \mathrm{yr}^{-1}$ (metric tons per year) global dust source strength, including 390,1960 , and $650 \mathrm{Mt} \cdot \mathrm{yr}^{-1}$ for particle size distribution of $0.5-1,1-25$, and $25-50 \mu \mathrm{m}$, respectively. It has been observed that atmospheric dust affects climate globally through its influence on the radiation balance of the atmosphere [5-8]. Similarly, on a regional scale, the presence of high concentrations of atmospheric dust affects economies by lowering visibility with an increase in cost of visibility impairment on national parks and wilderness areas as well as causing health problems [9-17]. It is also a major geomorphological factor for land degradation in arid regions [18]. High concentrations of dust at the local level may indicate agricultural soils are being degraded by the 
loss of fine particles [19]. Many previous studies have shown a positive correlation between drought years and increased dust emission $[18,20]$, while others indicated the entry of dust in the atmosphere occurs once the freshly deposited sediment brought by the intense storms becomes desiccated [21]. The capacity of the wind to entrain particles (erosivity), the soil's susceptibility to entrainment (erodibility), and the supply of erodible sediment are three major controls on the dust emission process [22]. The frequency and impact of dust events are controlled, in part, by the climatological and meteorological characteristics of a particular area [23].

In the context of surface characteristics to ablate the dust from the surface from our study region (i.e., southwestern U.S.), Okin and Reheis [18] revealed that the presence of fine grained wind erodible sediments and a dry climate facilitate a situation in which wind erosion may influence the southwestern U.S. The genesis, transport, and deposition of wind-blown dust constitute an important set of geomorphic, atmospheric, and ecologic processes in the drylands of the southwestern U.S. [24-26]. Mitchell et al. [27] stated that the western U.S. experiences an approximate 22-year drought cycle and that these drought cycles are normally periods of increasing dust storm activity. A study carried out over Southern California and Nevada by Reheis [28] revealed that alluvial deposits are major dust sources during long periods of dusty conditions. Neff et al. [29] showed that sediment cores recovered from alpine lakes downwind of southwestern drylands revealed strong proof for large increases in dust flux during the past $\sim 150$ years because of land use impacts, especially those caused by grazing and industrialization [30]. Recent research has indicated that the southwestern U.S. and northern Mexico have the potential to become dominant regional dust sources in the future [31,32].

Although a number of studies about the origin, transport, and deposition of desert dust are available $[19,23,28,33,34]$, a detailed understanding of the climatological and meteorological characteristics that influence dust event frequency and magnitude for sub-regions of the southwestern region of the U.S. are still lacking. This type of knowledge is needed to understand the regional and local dust climatology. The specific area of interest for this study is the area surrounding the NASA DFRC in Lancaster, California. The NASA DFRC mission is to conduct and support research, development, test, and evaluate manned and unmanned aerospace systems. Airfield operations on the lakebed are an essential part of these activities. It has been seen that due to extreme winds (e.g., Santa Ana) and dust storms over the southern California Mojave Desert result there is significant decrease in visibility, effects in aviation and ground transportation operations, and poor air quality conditions [35]. As the NASA DFRC lies in the Southern California Mojave Desert region, these aforesaid effects caused by dust storms may obviously affect the NASA DFRC and its performance. Therefore, to know the existing condition of dust events at and around NASA DFRC, a study of dust climatology of the NASA DRFC has been carried out here. This will be accomplished through an analysis of available climatological and meteorological data to identify what conditions were associated with dust emission events. Studying the weather systems, magnitude and direction of wind, the conditions of visibility, and the level of $\mathrm{PM}_{10}$ in ambient air reveal the onset, evolution and termination of dust events [36], and the commensurate degradation of air quality [34,37].

\section{Materials and Methods}

The NASA DFRC lies within Antelope Valley, a large closed hydrologic basin, situated in the southwest corner of the Mojave Desert of California. The NASA DFRC is situated at $34^{\circ} 54^{\prime} 20^{\prime \prime} \mathrm{N}$ and $117^{\circ} 53^{\prime} 01^{\prime \prime} \mathrm{W}$ at an elevation of $702 \mathrm{~m}$ above mean sea level (msl). This area is characterized by northwest-southeast trending dry valleys, confined by mountains reaching $2862 \mathrm{~m}$ in elevation, some of which are forested at higher elevations. The climate is continental desert and semi-arid to arid. There are intermittently flooded playas in the dry valleys. Winter temperatures can drop below freezing, whereas summer temperatures often exceed $38^{\circ} \mathrm{C}$. Most of the precipitation falls in the winter as rain or snow due to the passage of fronts, with a few monsoonal-type convective events forming in the summer. Mean annual rainfall for the area is $127 \mathrm{~mm}$. 
For the study of dust climatology of NASA DRFC, a daily meteorological data (1997-2011) record for EAFB in Lancaster, California was collected from wunderground.com [38] since this EAFB station is very close to NASA DFRC (Figure 1) [35]. Recorded meteorological data included visibility, wind speed, wind direction, relative humidity, and precipitation. These data were updated hourly, or more frequently when detrimental weather affecting aviation occurs (e.g., low visibility). Since data were not available in certain days of certain months of certain years, a continuous record of data could not be assembled. In this study, the critical meteorological data that were associated the observation of dust according to wunderground.com were applied, The National Weather Service (NWS) labels dust events at the time of observation when the prevailing station visibility is $\leq 1 \mathrm{~km}$. Orgill and Sehmel [39] defined a dust event condition when visibility is less than $\leq 11.2 \mathrm{~km}$. Similarly, Changery [36] analyzed $<11.2 \mathrm{~km},<8 \mathrm{~km},<4.8 \mathrm{~km},<1.6 \mathrm{~km}$, and $<1 \mathrm{~km}$ visibility ranges to study the dust climatology of the western U.S.. No single accepted definition of visibility range to define dust storm conditions exists. In this study, following Changery [36], these visibility criteria were used to examine their relationship with dust events and meteorological conditions: $<11.2 \mathrm{~km},<8 \mathrm{~km},<4.8 \mathrm{~km},<1.6 \mathrm{~km}$, and $<1 \mathrm{~km}$. During these visibility conditions of those particular days which were taken into account in this study, wunderground.com marked that there were occurrence of dust events at EAFB, which is very close to NASA DFRC. Therefore, this denies the roles of aerosols or other meteorological conditions influencing visibility except the dust events. Visibility is automated instantaneous data measured by a visibility sensor that has a maximum range of $32 \mathrm{~km}$. Visibility sensor sends light from a Xenon flash lamp in a cone-shaped beam and the receiver measures only the light scattered forward. Visibility data were updated hourly, or more frequently when detrimental weather affecting aviation occurs (e.g., low visibility).

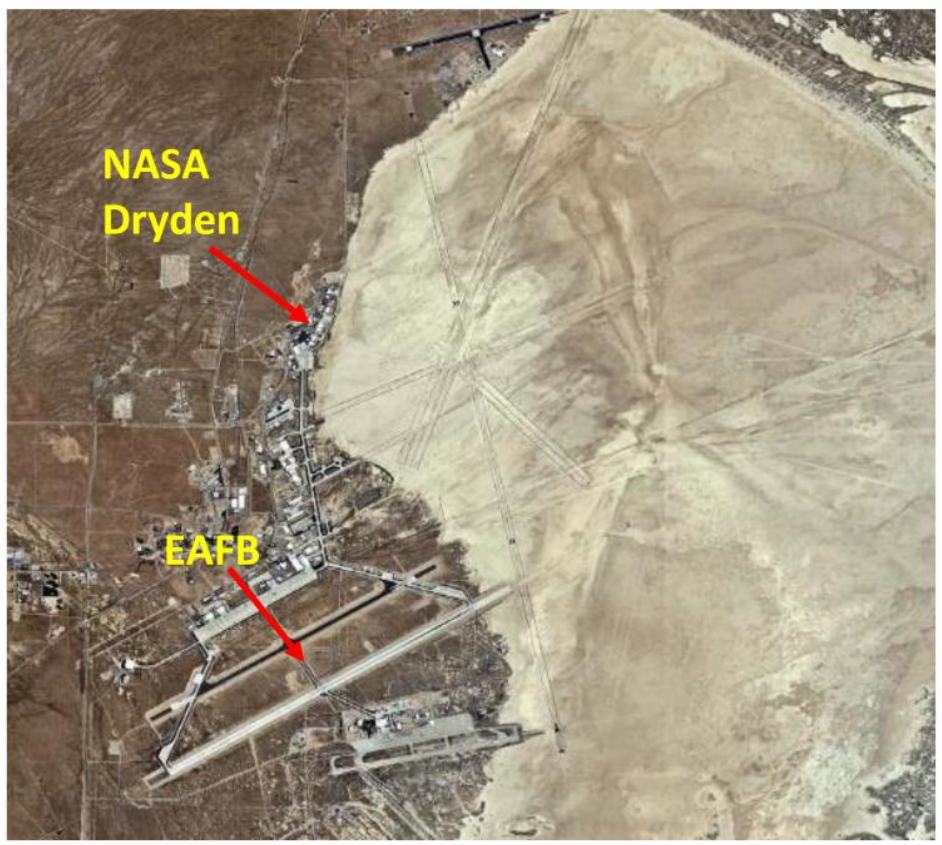

Figure 1. Satellite image of Rogers Dry Lake showing Edwards air field information-runways, which also lie within Antelope valley. This also shows locations of the NASA Dryden and Edwards AFB.

To link dust events with synoptic meteorological systems, data were collected from NCEP/(NARR) (32 km resolution), NCEP/Hydro-meteorological Prediction Center/NWS, and Unisys analyses that characterized the planetary boundary depth analysis (900-600 hPa), turbulent kinetic energy (900-600 hPa), upper air wind speed and direction, and jet streak analysis (900-600 hPa), pressure reduced to mean sea level to see a constant elevation sea level chart commonly known as surface 
weather map, temperature analysis $(900-600 \mathrm{hPa})$, sensible heat flux $(900-600 \mathrm{hPa})$, soil moisture content $(0-200 \mathrm{~cm})$, and volumetric soil moisture fraction $(0-10 \mathrm{~cm})[40]$.

\section{Results and Discussion}

\subsection{Wind Rose Associated with Dust and no Dust Events}

A wind rose associated with dust events is an important illustration to understand the directional components of the dust-laden winds for the area of interest. Wind roses showing sixteen wind direction bins for dust events with visibilities $<11.2 \mathrm{~km}$ were developed and are shown in Figure 2a. Similarly, wind roses for no dust events with visibilities $<11.2 \mathrm{~km}$ were also developed and are shown in Figure 2b. Figure 2a shows that during periods of decreased visibility that meet the set criteria $(<11.2 \mathrm{~km})$, the wind directions most frequently associated with visibility degradation was southwest $(18 \%)$, west-northwest $(18 \%)$, and west $(15 \%)$.

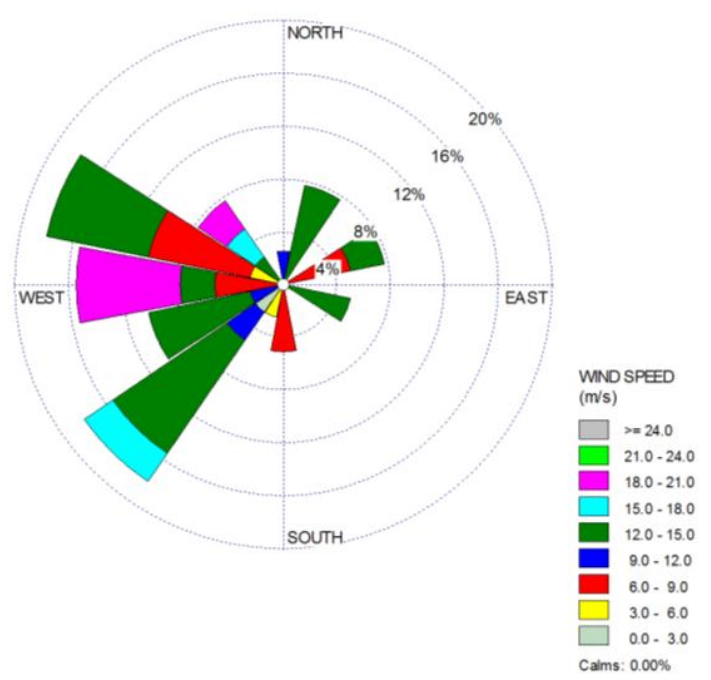

(a)

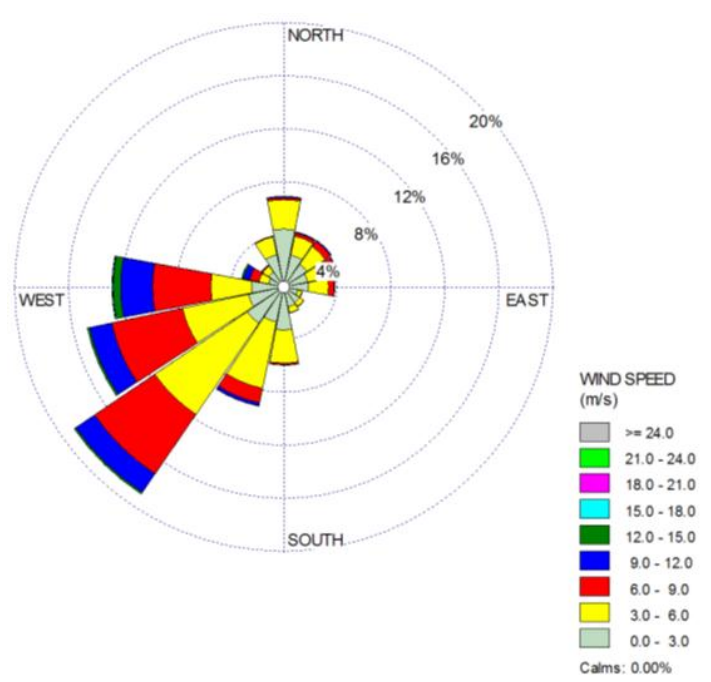

(b)

Figure 2. (a) Dust event wind rose; (b) No dust event wind rose.

3.2. Annual Number of Dust Events, Annual Mean Number of Dust Events, Annual Mean Duration of Dust Events, and Ratio of Duration and Number of Dust Events

Based on the number and time of dust events for the study period, we observe that 2007 had the highest number of dust events, 13 followed by 7, 6, and 6 in 1997, 2000, and 2009, respectively for the $<11.2 \mathrm{~km}$ visibility criterion shown in annual time series vs. annual frequency of dust events (Figure 3). It is important to note here that as this study is mainly focused on the study of the meteorological conditions associated with dust events, but not for finding the reason of occurrence of dust events and no dust events, detail understanding of causes of dust events in 1997, 1998, 2000, 2002, 2003, 2004, 2006, 2007, 2008, 2009, and 2011 and no dust events in 1999, 2001, 2005, and 2010 (Figure 3) are not emphasized in this study.

For the analysis of annual mean number of dust events, annual mean duration of dust events, and ratio of duration and number of dust events, first, all the dust event days and time corresponding to visibilities were selected and grouped from the last 15 years of recorded data. We note that in many cases, dust events displayed multiple occurrences below a visibility range in a given storm, since the storm alternatively weakened and strengthened. Each occurrence was counted as an event. It is seen that the annual mean number of dust events, annual mean duration of dust events, and ratio of duration to number of dust events were positively correlated for each visibility range shown in 
Figure 4. These parameters provide an indication of the duration and strength characteristics of a dust event in this region of California.

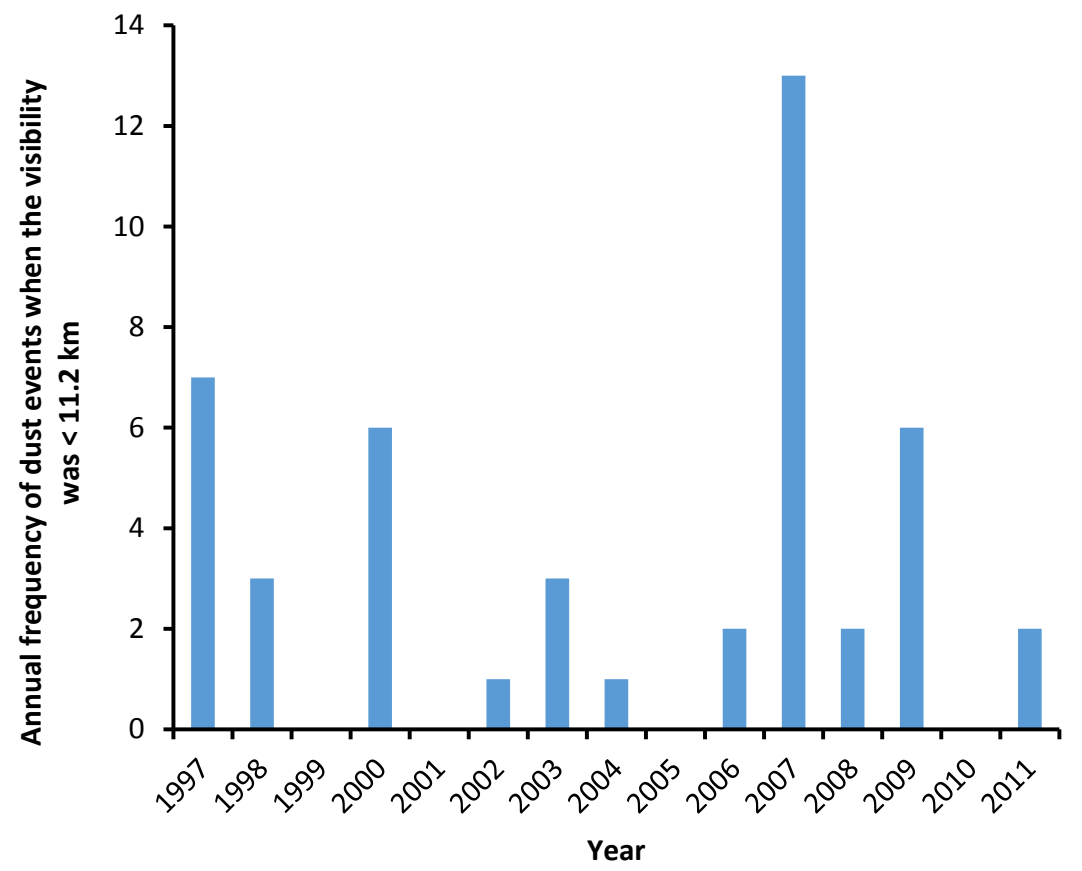

Figure 3. Annual number of dust events when the visibility was $<11.2 \mathrm{~km}$.

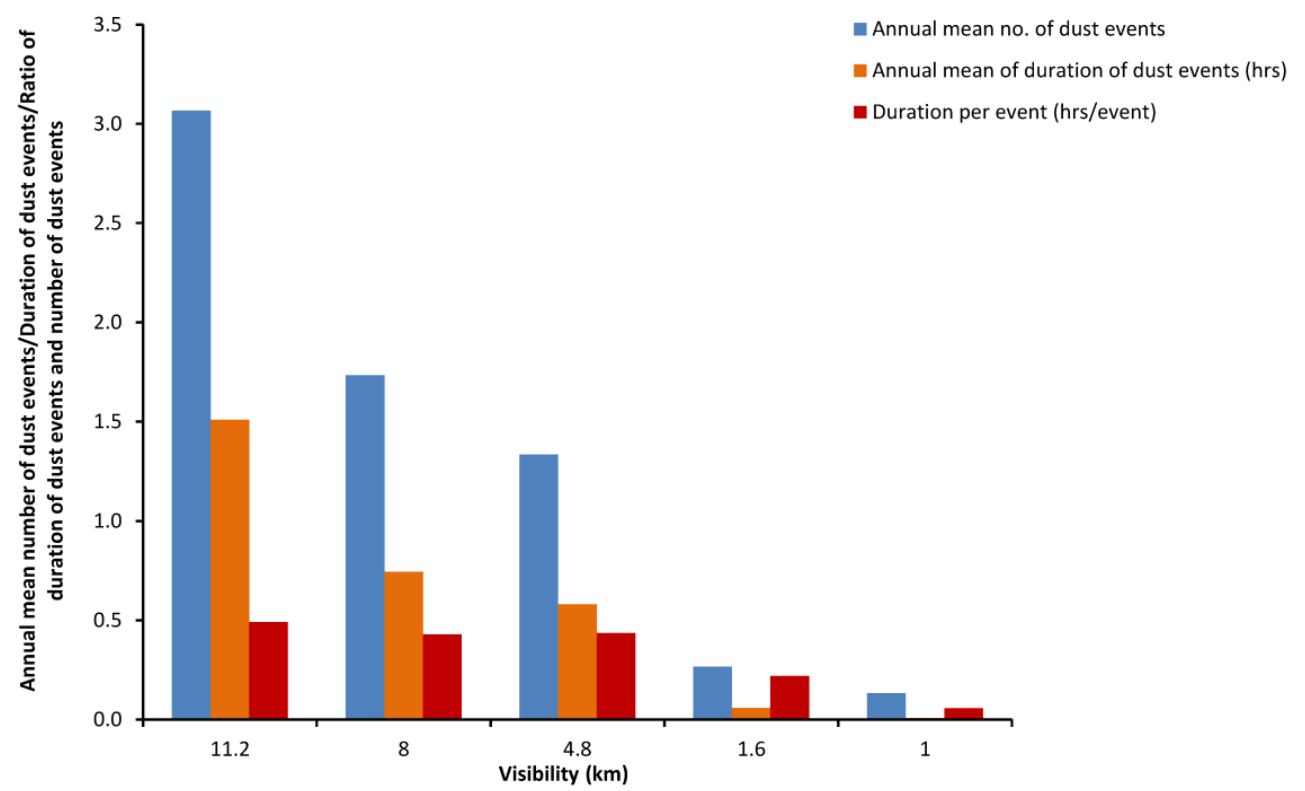

Figure 4. Annual mean number of dust events, annual mean duration of dust events, and ratio of duration and number of dust events.

The dust events data indicates that the time of onset of dust events had no consistency occurring at any time during a 24-h period. This is in contrast to dust events in Yuma, Phoenix, Winslow, and Tucson in Arizona, USA described by Brazel and Nicking [41], which usually occurred in the mid to late afternoon due to a maximum in atmospheric instability and the associated high convectively-forced wind speeds. Applying the lower visibility criterion for dust events to $<1.6 \mathrm{~km}$, reduces the number of dust event values compared to other higher values such as $<11.2 \mathrm{~km},<8 \mathrm{~km}$, and $<4.8 \mathrm{~km}$, which is 
also supported by Nicking and Brazel [23] stating that the number of dust events at Yuma and Phoenix, Arizona increased by $290 \%$ and $140 \%$ if the visibility criterion was changed from $<1.6 \mathrm{~km}$ to $<11.3 \mathrm{~km}$, respectively. Hagen and Woodruff [42] assumed dust was responsible for reducing the visibility on dusty days when the visibility ranged from 11.3 to $14.5 \mathrm{~km}$ and wind speed exceeded $5.4 \mathrm{~m} / \mathrm{s}$ in the Great Plains. They also found that the average dust storm duration was $6.6 \mathrm{~h}$ in the Great Plains. Orgill and Sehmel [39] stated that the southern Great Plains experienced the highest number of dust events followed by the western States, northern Great Plains, southern coastal Pacific and inland valleys and the Southeast. Changery [36], based on a 30 year dust event analysis (1948-1977) for the area near EAFB, California, reported annual mean durations of dust events of 1.75, 0.47, 0.19, and $0.17 \mathrm{~h}$ for the visibility conditions $<11.2,<4.8,<1.6$, and $<1 \mathrm{~km}$, respectively. When comparing Changery's [36] results with our results for the NASA DFRC area, the duration of dust events as a function of visibility is lower in all cases for our results. This study also reveals an important information that dust events typically did not last very long (under $2 \mathrm{~h}$ ) in the DFRC study region, which might be constrain of visibility criteria $(<11.2 \mathrm{~km})$ since we only considered the duration of the dust storms when the visibility was $<11.2 \mathrm{~km}$.

\subsection{The Seasonal Percentage of Dust Events and Visibility}

To evaluate the seasonality of dust events, the identified occurrences were categorized based on the day of their occurrence into bins for the four seasons-winter (Dec., Jan., and Feb.), spring (March, April, and May), summer (June, July, and Aug.), and autumn (Sept., Oct., and Nov.). The occurrence of dust events by season was expressed as a percentage of the total number of annual dust events and is shown in Figure 5. The visibility reduction of each season was categorized into $<11.2,<8,<4.8,<1.6$, and $<1 \mathrm{~km}$ ranges and expressed as a percent frequency of occurrence, which is presented as a histogram in Figure 6 . The percentage of total dust events by season indicate that most dust events over the last 15 years occurred in autumn (44.7\%) followed by spring (38.3\%) and equally in summer and winter with these seasons each accounting for $8.5 \%$ of events (Figure 5).

The magnitude of visibility reduction in percentage and by season shows that the lowest visibility condition $(<1 \mathrm{~km})$ occurred most often in summer $(10 \%)$, followed by autumn (2\%) (Figure 6). Neither of the other two seasons (winter and spring) had dust events reaching this low visibility condition during the entire 15 year record. Dust events in winter had the least visibility impairment with $67 \%$ having visibility $<11.2 \mathrm{~km}$. In spring, $55 \%$ of all events had visibility reduction $<11.2 \mathrm{~km}$. The results also indicate that summer events had the highest percent occurrence $(10 \%)$ of severe dust events (i.e., visibility $<1.6 \mathrm{~km}$ and $<1 \mathrm{~km}$ ) followed by autumn with $4 \%$ and $2 \%$ of severe events respectively (Figure 6), which is similar to the findings of Nicking and Brazel [23] and indicative of dust generated by deep convective phenomena in the atmosphere. For the NASA DFRC area in winter and spring seasons, there were no recorded dust events over the last 15 years that reached these low visibility conditions. For the visibility criteria $<4.8 \mathrm{~km}$, autumn experienced the highest dust event frequency ( $24 \%$ of total events) followed by summer $(20 \%)$, and spring with $16 \%$. This is consistent with Tong et al. [34], who reported that peak dust emission occurred in spring, summer, and autumn over the western US. Changery [36] stated that southern Arizona and extreme southern California experienced most of the dust events in the summer. The remaining part of the California and southern Nevada regions experienced the majority of the dust events in the autumn and winter. In contrast, our study area experienced the highest percentage (67\%) in winter for the $<11.2 \mathrm{~km}$ visibility criterion followed by spring (55\%), autumn (41\%), and summer $(40 \%)$. 


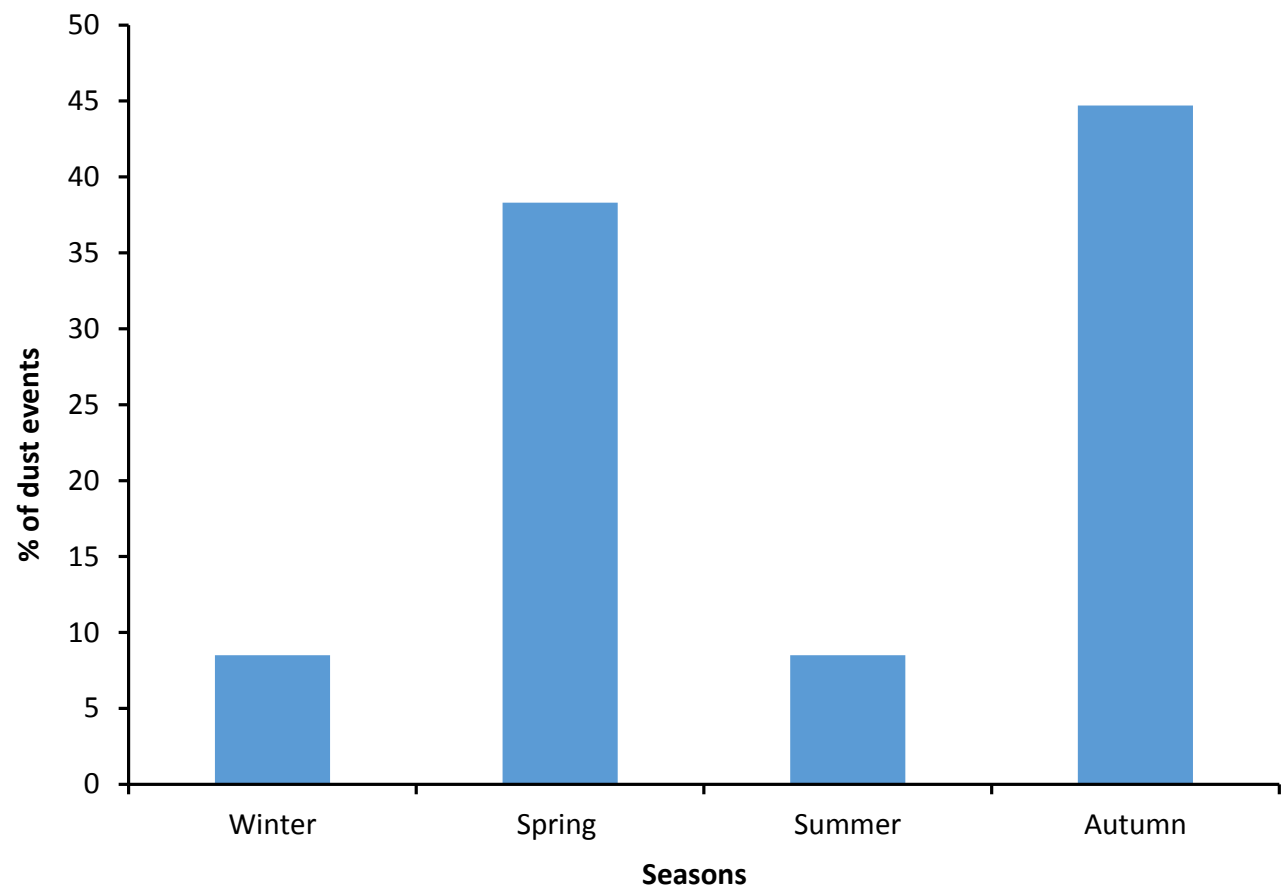

Figure 5. Seasonal percentage of the dust events.

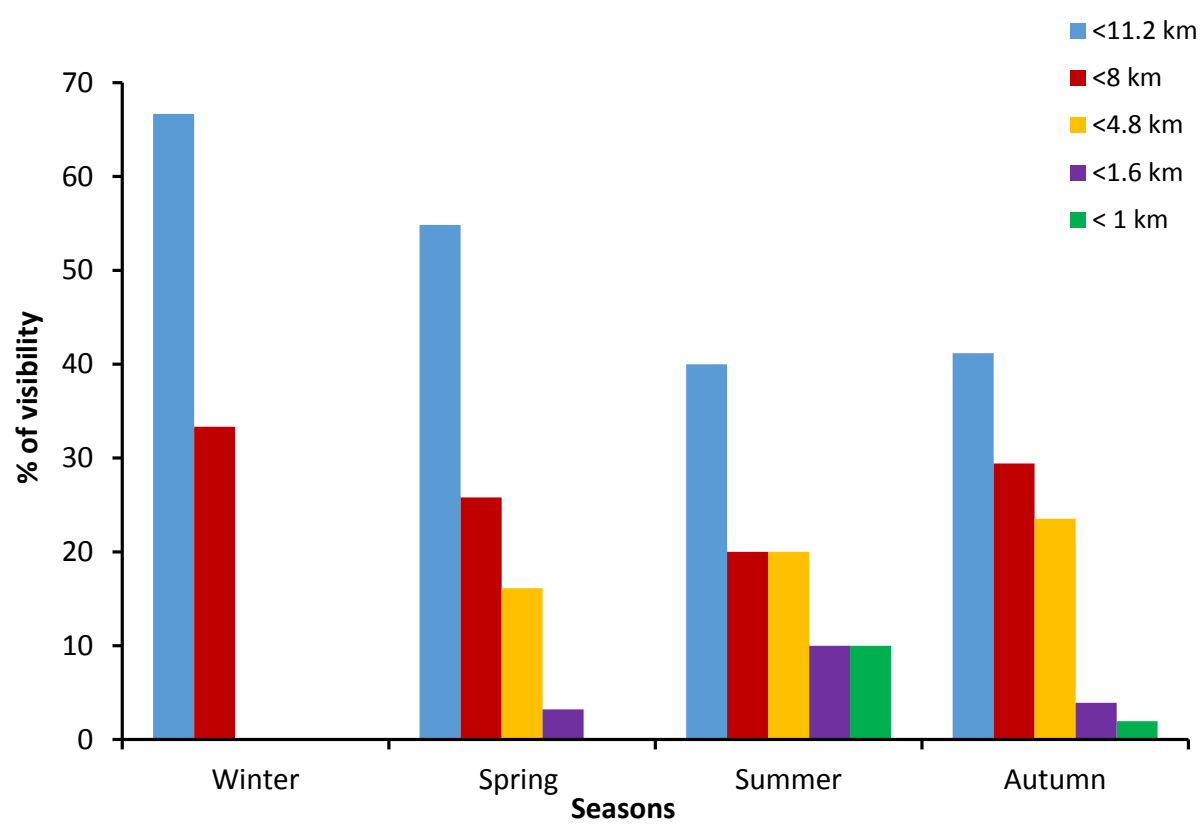

Figure 6. Visibility strength in seasons.

\subsection{Relative Humidity and Precipitation during Dust Events}

Dust events were observed during the lower relative humidity (RH) days [43-45]. The RH in each dust event and the average RH for all dust events is also shown here in Figure 7. For the entire record of dust events (1997-2011) in our study, the relative humidity (RH) ranged from $8 \%$ to $63 \%$. The average RH for all dust events was $36.5 \% \pm 16.0 \%$, which is higher than $15 \%-20 \%$ RH observed by Novlan et al. [44] in El Paso, Texas, USA. There were also some dust storms cases observed in different geographical region in different $\mathrm{RH}$ conditions, such as at $68.64 \% \pm 11.36 \%$ and $68.02 \% \pm 10.31 \% \mathrm{RH}$ observed by Chen et al. [43] and Yang et al. [45], respectively, during dust events in Taipei. 


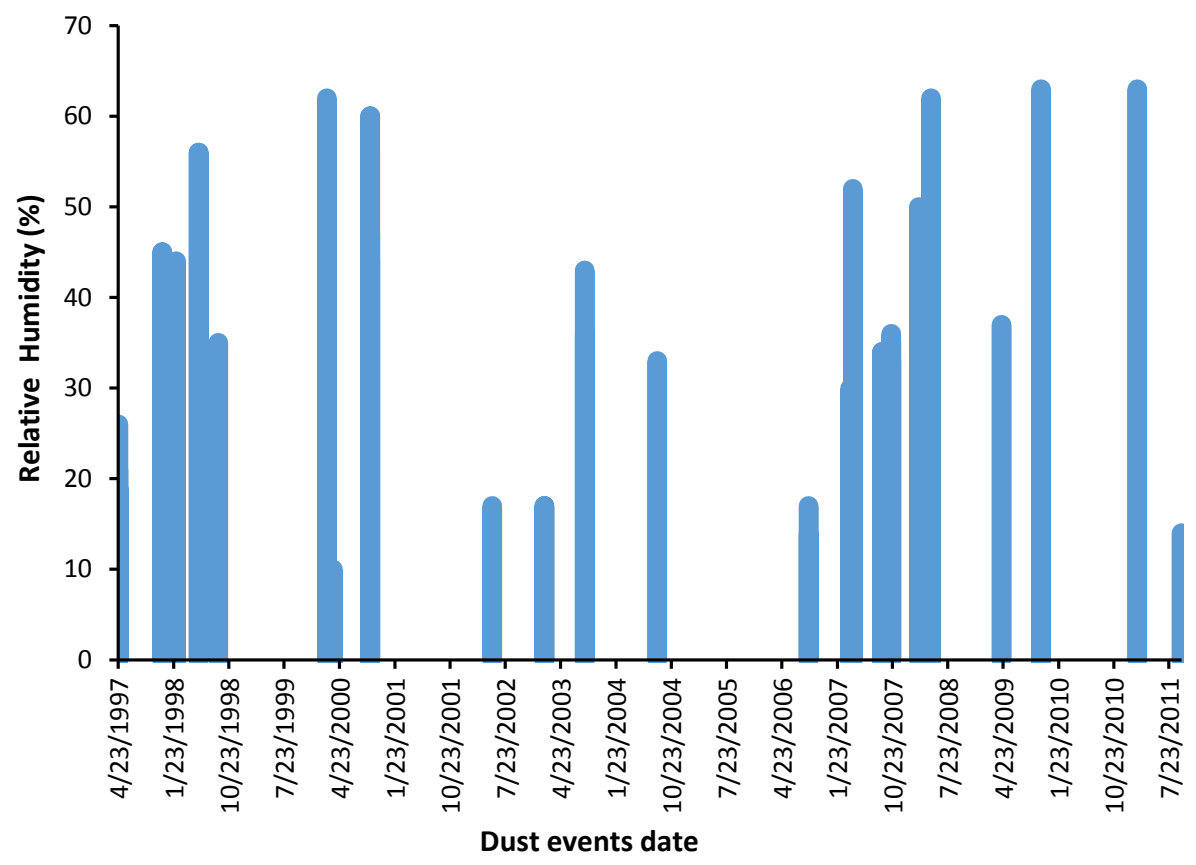

Figure 7. Relative Humidity.

The total annual precipitation amounts over the last fifteen years (1997-2011) were also calculated from the data records, categorized by season and shown in Figure 8. Figure 8 shows that the average annual precipitation in the area surrounding the NASA DFRC was determined to be $278.18 \mathrm{~mm}$ with a standard deviation of $\pm 241.84 \mathrm{~mm}$. The monthly precipitation values were combined to provide seasonal precipitation amounts, which are also shown in Figure 8. The annual precipitation amounts in 1999, 2000, 2002, 2003, 2004, 2005, 2006, 2007, 2008, 2010, and 2011 were lower than the long-term average annual precipitation ( $278.18 \mathrm{~mm}$ with a standard deviation of $\pm 241.84 \mathrm{~mm}$ ) by $73.6 \%, 40 \%$, $93 \%, 15 \%, 72.4 \%, 27.6 \%, 67.5 \%, 22.1 \%, 39.6 \%, 24.7 \%$, and $45.2 \%$, respectively. The numbers of dust events in these consecutive years were, $0,6,1,3,1,0,2,13,2,0$, and 2, respectively. This shows that NASA DFRC experienced annual precipitation below than average annual precipitation for 11 years out of total 15 years of study period.

The relationship between the percent contribution of precipitation to the total annual amount and dust events by season is shown in Figure 9. Figure 9 shows that the greatest percentage of precipitation occurred in the winter $(46.29 \%)$, followed by summer $(28.55 \%)$, spring $(15.55 \%)$, and autumn $(9.61 \%)$ Hagen and Woodruff [42] found that most areas of the Great Plains experienced a significant number of dust hours during low annual precipitation. Our results, which are shown in Figure 9, indicate a consistency regarding precipitation versus dust events. It reveals that the higher the percentage of total precipitation, the lower the total dust events percentage in the winter and the summer. Similarly, the lower the percentage of total precipitation, the higher the total dust event percentage in the spring and the autumn. For the spring, these results are consistent with the conclusion of Reheis and Kihl [21] that greater amounts of precipitation can increase the delivery of sediment or rework previously deposited sediments in closed basins, which increases the potential for deflation once this sediment dries out. In winter, the lower frequency of dust events might be due to the effect of moderate precipitation in terms of magnitude and intensity, which increased the threshold for wind erosion by increasing the soil moisture content, which increased the binding energy between particles [46]. Intense summer precipitation from thunderstorms can also deliver sufficient amounts of water to the soil to increase the soil moisture thus increasing threshold wind speeds for deflation until levels decreased to critical levels due to evaporation. 


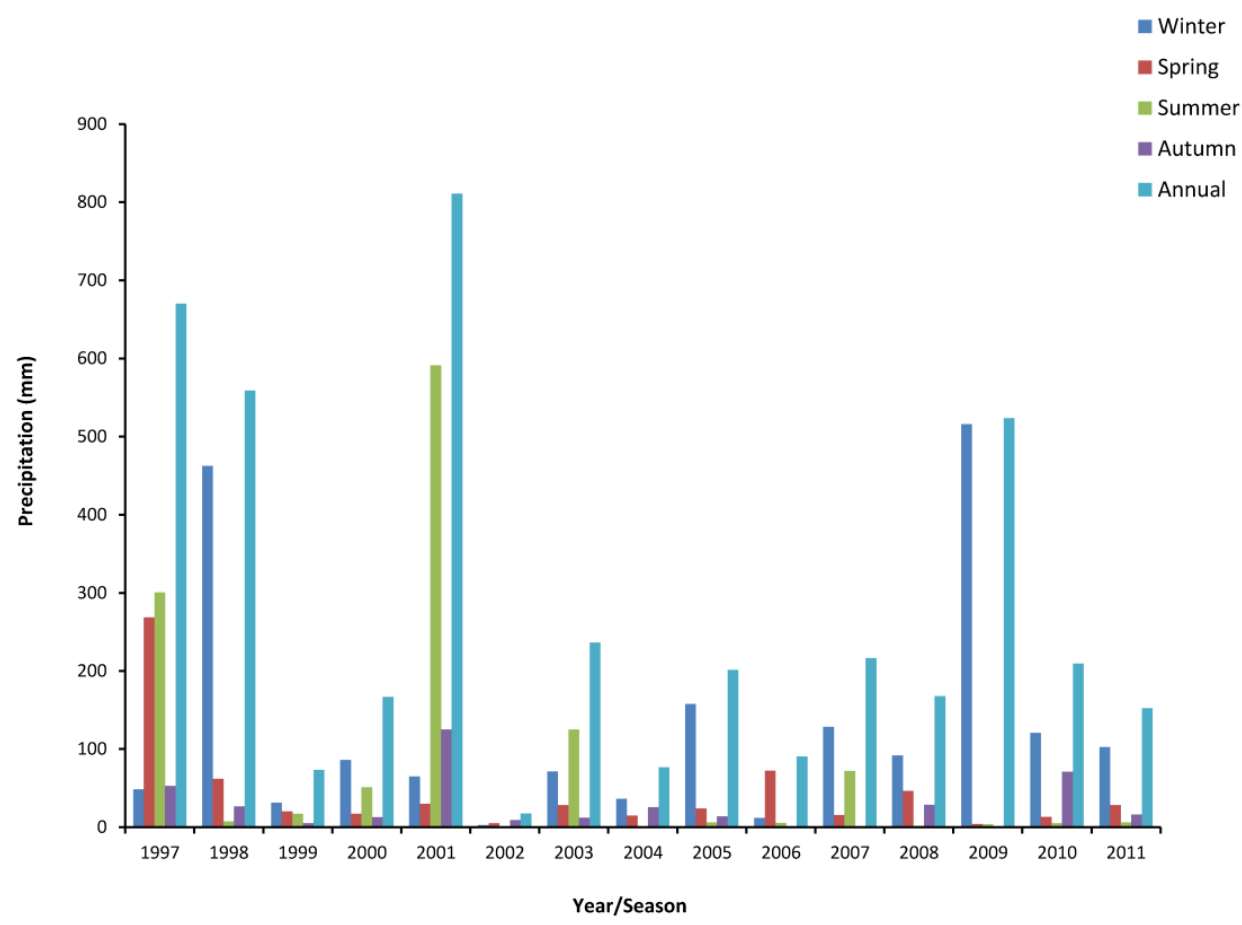

Figure 8. Annual and seasonal precipitation.

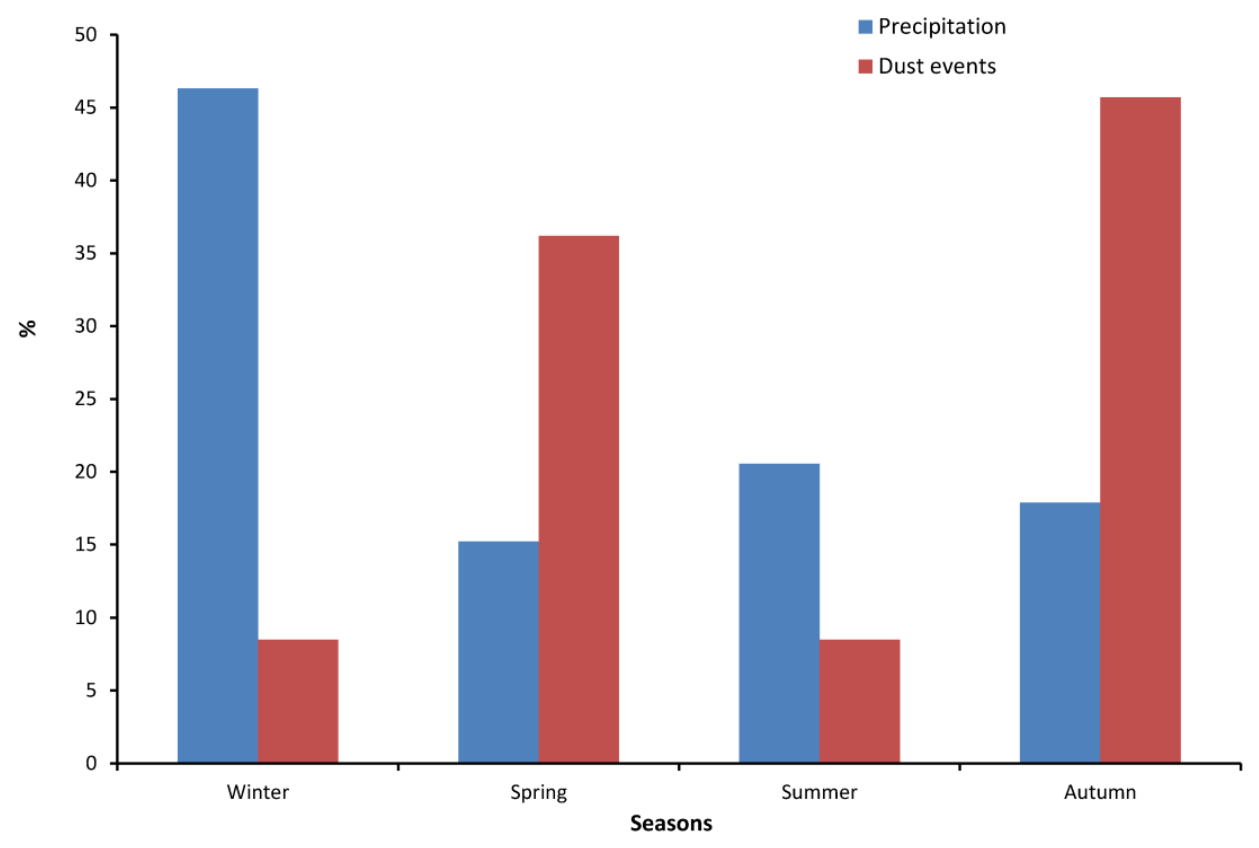

Figure 9. Seasonal precipitation and dust events.

\subsection{Frequency of Wind Speed during Dust and No Dust Events}

The frequency of wind speed when there were dust events and the frequency of occurrence of high wind speed $\geq 11.55 \mathrm{~m} / \mathrm{s}$ when there were no dust events were calculated to quantify the ranges of the wind speed responsible for the dust event and the maximum number of wind speed ranges during no dust event, respectively. The wind speed bins were 3.6-11.0, 11.0-12.5, 12.5-14.0, 14.0-15.5, $15.5-17.0,17.0-18.5,18.5-20,20.0-21.5$, and $21.5-23.0$ and 11.0-12.5, 12.5-14.0, 14.0-15.5, 15.5-17.0, $17.0-18.5,18.5-20,20.0-21.5,21.5-23.0,23.0-24.5,24.5-26.0,26.0-27.5$, and $27.5-29.0 \mathrm{~m} / \mathrm{s}$ and the corresponding frequency of occurrence in each bin for the dust event and no dust event are shown 
in Figures 10 and 11, respectively. Figure 10 shows that the wind speed bin of $3.6-11 \mathrm{~m} / \mathrm{s}$ had the highest frequency of $26 \%$ within the entire group of dust events. Since the cumulative frequency of wind speed has sharply increased from $3.6-11.0 \mathrm{~m} / \mathrm{s}$ to $12.5-14.0 \mathrm{~m} / \mathrm{s}$ indicating the $7.3 \mathrm{~m} / \mathrm{s}$ (mean of $3.6-11.0 \mathrm{~m} / \mathrm{s}$ ) $-13.25 \mathrm{~m} / \mathrm{s}$ (mean of $12.5-14.0 \mathrm{~m} / \mathrm{s}$ ) wind speed played a crucial role in causing the dust events (Figure 10). This value is a little bit lower than found in Hall [47], which stated that $15 \mathrm{~m} / \mathrm{s}$ wind speed was required to cause sand and dust storms in the southwestern U.S. The causes of difference of these two values could be defined by a detailed study regarding the interactions of antecedent moisture conditions, land use/vegetation patterns, surface structure, and the dust emission processes. The frequency of high wind speeds when there were no dust events was computed, which is shown in Figure 11, and has different bin ranges than Figure 10. Figure 11 shows that higher wind speed had lower frequency of the occurrence. It also shows that the wind speed range of $11.0-12.5 \mathrm{~m} / \mathrm{s}$ had the highest frequency of occurrence, which was 1004 out of 1926 days.

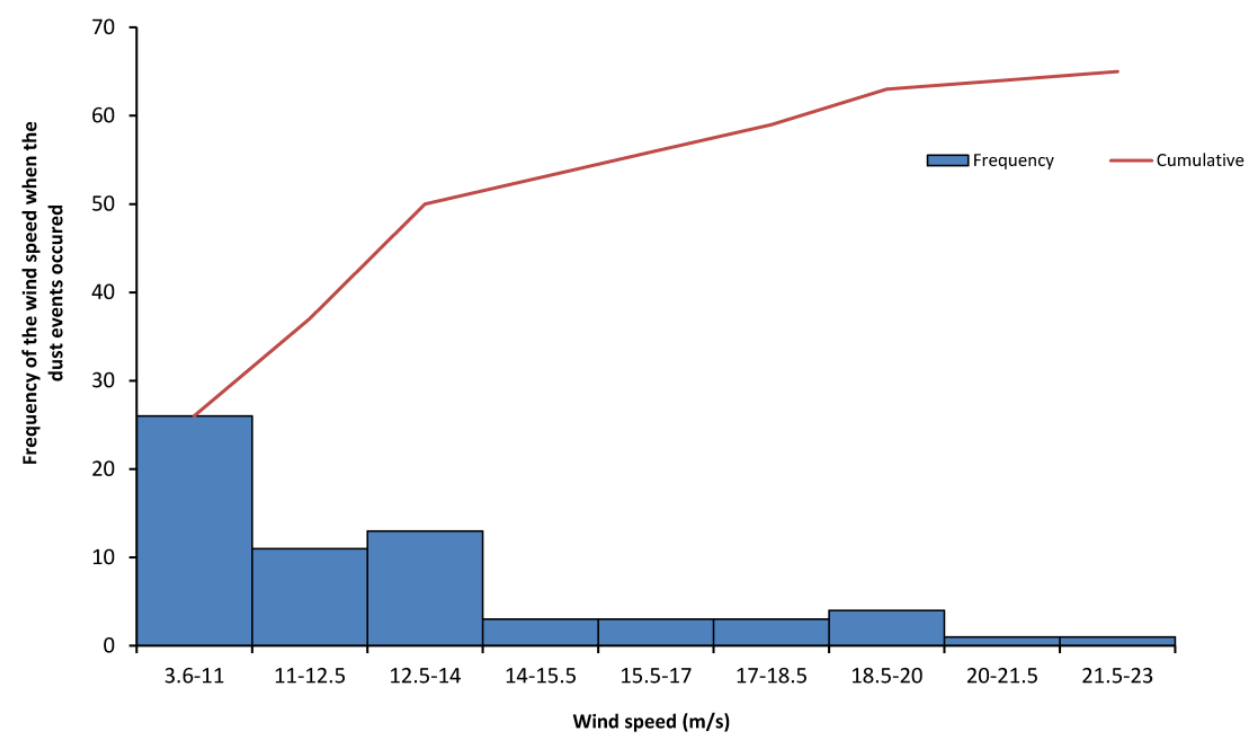

Figure 10. Frequency of the wind speed when the dust events occurred.

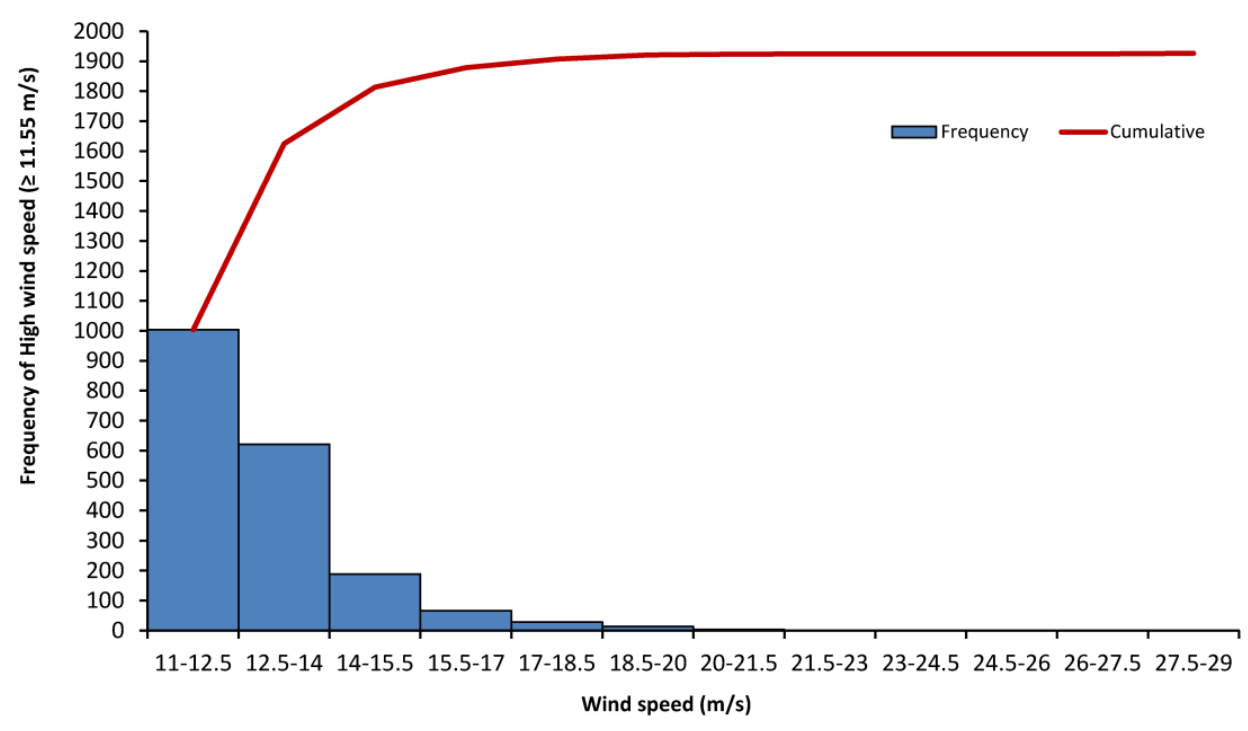

Figure 11. Frequency of the high wind speed when no dust events occurred. 


\subsection{Ratios of Number of Dust Events to No Dust Events}

The ratios of the number of dust events and no dust events to the total number of event days for different consecutive wind speeds were calculated and shown in Figure 12. It shows that the ratios of the no dust events were higher than ratios of the dust events up to a wind speed bin of 14.0-15.5 m/s. This shows that dust events occurred when the wind speed exceeds $15.5 \mathrm{~m} / \mathrm{s}$. Figure 12 also shows that ratios without the dust events were decreasing as the wind speed bin increased, but, in the case of the ratios of dust events, there was no such consistent trend of decreasing of ratios with wind speed.

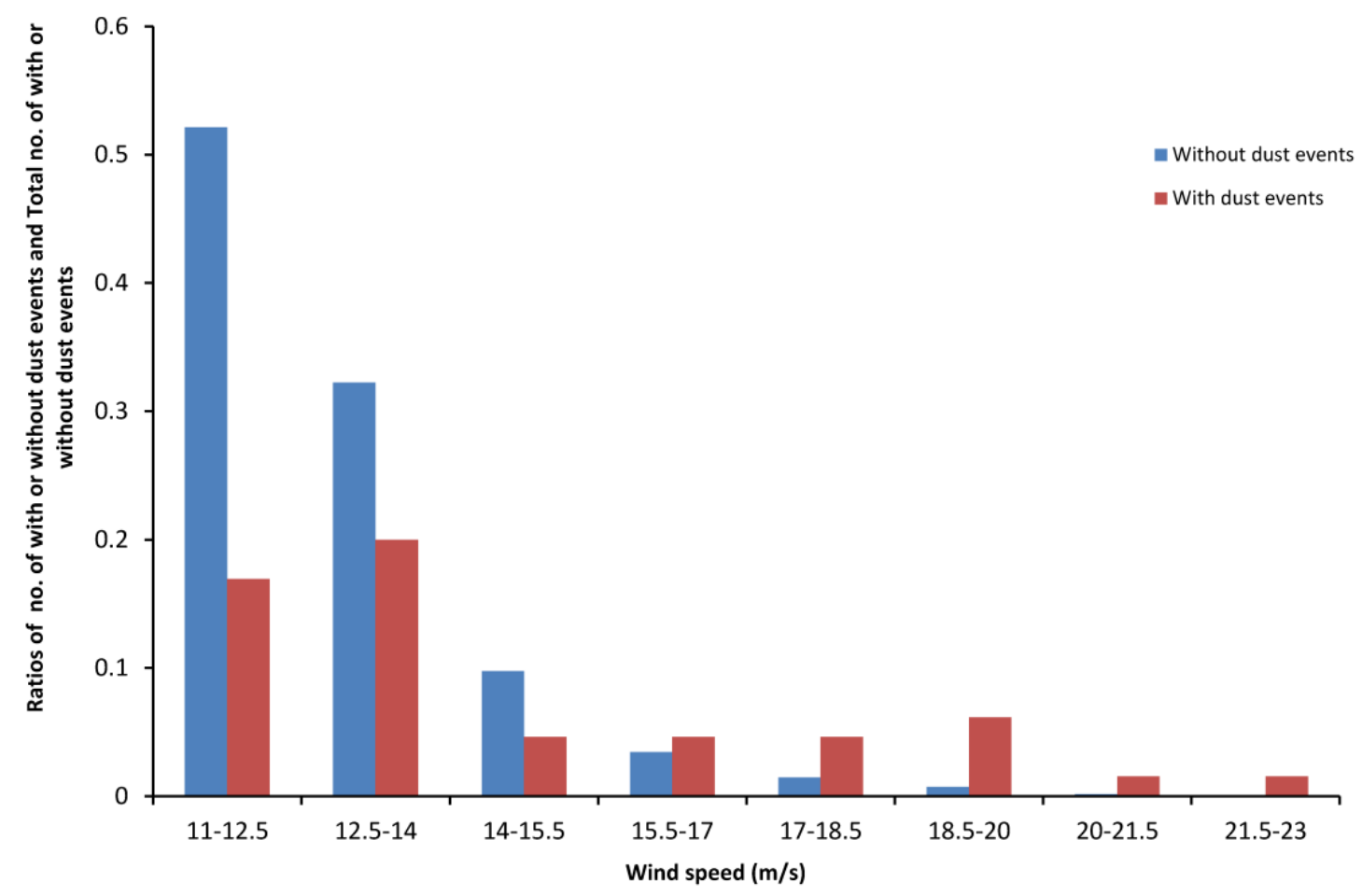

Figure 12. Ratio of number of with or without dust events and total number of with or without dust events.

\subsection{Meteorological Systems}

After analyzing the presence of meteorological and soil conditions during the dust events from 1997 to 2011 as per mentioned in the Table A1 of the Appendix A, it was summarized that these dust events were associated with the development of a deep convective boundary layer, a deep unstable lapse rate layer (a lapse rate between dry adiabatic and moist adiabatic which occupied $52 \%$ of total dust events), a high-intensity turbulent kinetic energy $\geq 3 \mathrm{~J} / \mathrm{kg}$ [48] (occupying 63\% of total dust events), a significant wind speed ( $\geq 7.3 \mathrm{~m} / \mathrm{s}$ which is the threshold frictional wind speed occupying $98 \%$ of total dust events), as well as the presence of a cold trough (occupying $96 \%$ of total dust events), a strong cyclonic jet (occupying $85 \%$ of total dust events), an influx of sensible heat flux from the surrounding area during dust event, and a low volumetric soil moisture fraction $(<0.3$ which occupied $100 \%$ of total dust events).

The presence of deep convective PBL over the NASA DFRC area during the dust events in our study are consistent with Danielsen $[49,50]$ which all showed that dust events were associated with intense wind fields and deep mixed layers adjoining the surface. The presence of an unstable lapse rate during the dust produced a deep mixed layer to facilitate mixing down higher momentum winds to the surface to cause the dust event [44,51]. There was high intensity TKE of $\leq 3 \mathrm{~J} / \mathrm{kg}$ consistent with Kaplan et al. [48]. We see that dust emission occurred when the wind speed near the surface exceeded the threshold friction velocity [52], which was $\geq 7.3 \mathrm{~m} / \mathrm{s}$. Dust events were associated with 
the presence of cold troughs above the deep PBL, which support the findings of Shimzu et al. [53] stating that significant transport of dust was observed after the passage of cold trough from the Gobi and/or Taklamakan Deserts. The mass and momentum adjustments accompanying the propagation of an upper level cyclonic jet streak observed in our study favored the development of convective storms that caused dust events, which agree with the findings of Karyampudi et al. [54] and Lewis et al. [55]. During the period prior to dust storm formation cold air was transported above the heated ground which produced a large magnitude of sensible heat flux to the atmosphere. This depleted the ground of heat after the dust storm event. The presence of low volumetric soil moisture reduced the cooling due to latent heat flux thus accentuating the transfer of heat from the Earth's surface to the atmosphere.

\subsection{The Weather Events Followed by Dust Events}

Alteration of the threshold friction velocity for the emission of the dust from the surface is controlled by weather events, such as non-convective rainfall and moist convection $[36,47,56,57]$. To characterize these weather events followed by dust events, all the dust events were grouped into non-convective rainfall followed by dust events, moist convection followed by dust events, non-convective rainfall and convective rainfall followed by dust events, and when none of those were present at the time of dust events as shown in Figure 13. After evaluating the weather events, such as non-convective rainfall followed by dust events, moist convection followed by dust events, non-convective rainfall and moist convection followed by dust events, and none of those, the results indicate that they occupied $12 \%, 11 \%, 5 \%$, and $72 \%$ of the total dust events, respectively (Figure 13). A dust event caused by moist convection is facilitated by the strong generation of the outflow of rain-cooled air from the cumulonimbus clouds [36]. This happens when the rain falling from these clouds evaporates and cools the surrounding air due to contact with the warm dry air below. The cool air, which is heavier, accelerates downward and strikes the surface and spreads out widely. In those conditions, winds generate dust events.

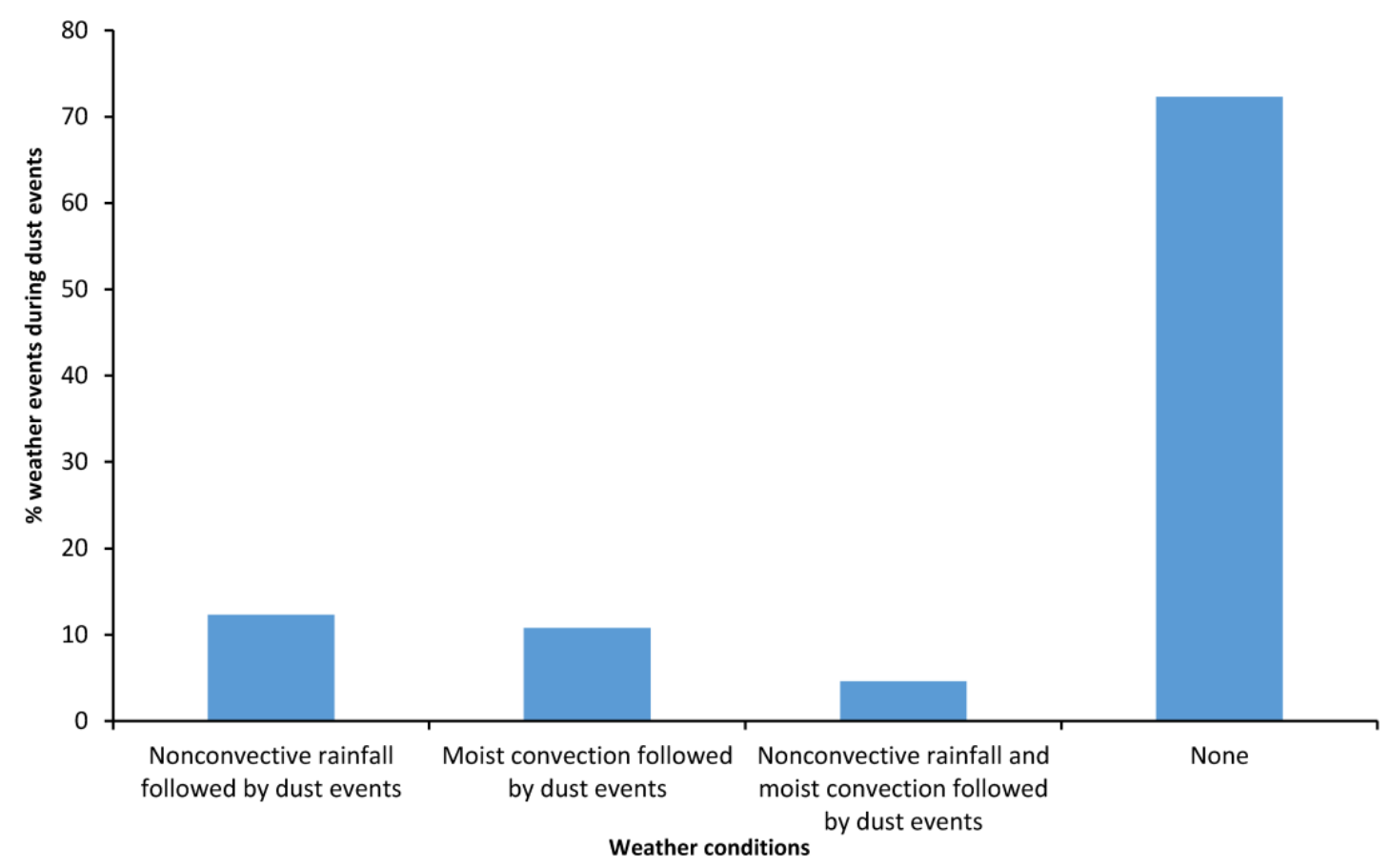

Figure 13. Weather followed by dust events. 


\section{Conclusions}

During the analyzed dust events, the major wind component directions were southwest, west-northwest, and west. We observe that the annual mean number of dust events, annual mean duration of dust events, and ratio of duration to number of dust events were positively correlated for each visibility range. We find that the higher the percentage of total precipitation, the lower the total dust events percentage in the summer and the winter, and the lower the percentage of total precipitation, the higher the total dust event percentage in the spring and the autumn. Dust events were associated with the development of a deep convective boundary layer, an unstable lapse rate, a high-intensity turbulent kinetic energy, a significant wind speed $(\geq 7.3 \mathrm{~m} / \mathrm{s})$, a presence of a cold trough, a strong cyclonic jet, an influx of sensible heat flux from the surrounding area during dust event, and a low volumetric soil moisture fraction. It is thought that this study will be broadly applicable to communities and facilities of not only NASA DFRC, but also the Mojave Desert Region as the information may be useful for developing strategies to mitigate the risks and vulnerabilities that could result from the current climatology of the dust events.

Acknowledgments: This work was partially supported by the NASA Dryden Flight Research Center. We would like to thank Jack A. Gillies and Fred Wohosky for providing supporting document and information related to this study and Dave Campbell for graphics help.

Author Contributions: Ashok K. Pokharel collected data, analyzed them, and prepared this manuscript and Michael L. Kaplan edited this manuscript and provided the additional information on it.

Conflicts of Interest: The authors declare that there are no conflicts of interest.

\section{Appendix A}

The Appendix includes a Table A1, which provides detailed meteorological parameters for identified dust events during the period from 1997 to 2011. 
Table A1. The magnitude of meteorological parameters for identified dust events during the period from 1997 to 2011.

\begin{tabular}{|c|c|c|c|c|c|c|c|c|c|c|c|c|c|c|}
\hline S.N. & Date & Season & Local Time & $\begin{array}{c}\text { Planetary } \\
\text { Boundary } \\
\text { Layer Depth } \\
\text { (m) (900-600 } \\
\text { hPa) }\end{array}$ & $\begin{array}{c}\text { Lapse Rate } \\
\left({ }^{\circ} \mathrm{C} / \mathrm{km}\right) \\
\left(\begin{array}{c}00-600 \\
\text { hPa })\end{array}\right.\end{array}$ & $\begin{array}{c}\text { Turbulent } \\
\text { Kinetic } \\
\text { Energy } \\
\text { (J/g) } \\
(900-600 \\
\text { hPa) }\end{array}$ & $\begin{array}{c}\text { Cold } \\
\text { Trough } \\
\left(\begin{array}{c}\text { (roo-600 } \\
\text { hPa) }\end{array}\right.\end{array}$ & $\underset{(\mathrm{m} / \mathrm{s})}{\text { Wind Speed }}$ & $\begin{array}{c}\text { Wind } \\
\text { Direction }\end{array}$ & $\begin{array}{c}\text { Cyclonic Jet } \\
\left(\begin{array}{c}(900-600 \\
\text { hPa) }\end{array}\right.\end{array}$ & $\begin{array}{c}\text { Influx of } \\
\text { Vertical } \\
\text { Sensible } \\
\text { Heat from } \\
(900-600 \\
\text { hPa) }\end{array}$ & $\begin{array}{l}\text { Soil } \\
\text { Temperature } \\
(0-10 \mathrm{~cm})^{\circ} \mathrm{C}\end{array}$ & $\begin{array}{c}\text { Soil } \\
\text { Moisture } \\
(0-200 \mathrm{~cm}) \\
\left(\mathrm{kg} / \mathrm{m}^{2}\right)\end{array}$ & $\begin{array}{c}\text { Volumetric } \\
\text { soil } \\
\text { Moisture } \\
\text { Fraction at } \\
0-10 \mathrm{~cm}\end{array}$ \\
\hline $\begin{array}{l}1 \\
2 \\
3 \\
4 \\
5 \\
6 \\
\end{array}$ & $\begin{array}{l}23 / 4 / 1997 \\
23 / 4 / 1997 \\
23 / 4 / 1997 \\
23 / 4 / 1997 \\
23 / 4 / 1997 \\
23 / 4 / 1997\end{array}$ & Spring & $\begin{array}{l}16: 55 \\
17: 22 \\
18: 22 \\
18: 38 \\
18: 55 \\
19: 11 \\
\end{array}$ & 3000 & 6 & $1-6$ & Yes & $5-32.5$ & Northwesterly & Yes & North & 32 & 500 & 0.1 \\
\hline 7 & 26/11/1997 & Autumn & $8: 31$ & 2000 & 4 & 1 & Yes & $10-37.5$ & Southwesterly & Yes & $\begin{array}{l}\text { West, North, } \\
\text { and East }\end{array}$ & 12 & 500 & 0.25 \\
\hline 8 & 3/2/1998 & Winter & 4:46 & 2500 & 3.5 & $1-2$ & Yes & $17.5-27.5$ & $\begin{array}{l}\text { Southwesterly, } \\
\text { Southeasterly }\end{array}$ & Yes & $\begin{array}{l}\text { West, North, } \\
\text { and South }\end{array}$ & 9 & 500 & 0.3 \\
\hline 9 & 25/5/1998 & Spring & $14: 48$ & 2500 & 4.6 & $1-4$ & Yes & $10-17.5$ & Southwesterly & Yes & $\begin{array}{l}\text { Northwestern, } \\
\text { Southwestern }\end{array}$ & 32 & 600 & 0.2 \\
\hline 10 & 31/8/1998 & Summer & 16:18 & 4500 & 7.5 & $2-6$ & Yes & $2.5-7.5$ & $\begin{array}{l}\text { Northerly, } \\
\text { Northwesterly }\end{array}$ & No & $\begin{array}{l}\text { North, } \\
\text { Southwestern }\end{array}$ & 47 & 500 & 0.12 \\
\hline 11 & 20/2/2000 & Winter & 8:02 & 1800 & 4.4 & $0.3-1$ & Yes & $7.5-20$ & $\begin{array}{l}\text { Southeasterly, } \\
\text { Southerly }\end{array}$ & Yes & $\begin{array}{l}\text { North, } \\
\text { Southwestern }\end{array}$ & 20 & 500 & 0.25 \\
\hline 12 & $20 / 3 / 2000$ & Spring & 10:45 & 4500 & 5.3 & $1-6$ & Yes & $15-20$ & Northerly & Yes & $\begin{array}{c}\text { North, } \\
\text { Southwestern }\end{array}$ & 17 & 500 & 0.25 \\
\hline $\begin{array}{l}13 \\
14 \\
15 \\
16 \\
\end{array}$ & $\begin{array}{l}21 / 9 / 2000 \\
21 / 9 / 2000 \\
21 / / / 2000 \\
21 / 9 / 2000 \\
\end{array}$ & Autumn & $\begin{array}{l}14: 44 \\
15: 31 \\
15: 55 \\
17: 17 \\
\end{array}$ & 2000 & 4.6 & $1-2$ & Yes & 7.5 & Southwesterly & No & $\begin{array}{l}\text { North, East, } \\
\text { South }\end{array}$ & 32 & 450 & 0.12 \\
\hline 17 & 19/5/2002 & Spring & 13:55 & 2500 & 5.5 & $1-4$ & Yes & $10-17.5$ & $\begin{array}{l}\text { Southwesterly, } \\
\text { Southerly }\end{array}$ & Yes & $\begin{array}{l}\text { North, East, } \\
\text { South }\end{array}$ & 32 & 500 & 0.15 \\
\hline 18 & $1 / 2 / 2003$ & Winter & $12: 28$ & 2000 & 6.5 & $0.5-1.5$ & Yes & $10-20$ & $\begin{array}{l}\text { Southwesterly, } \\
\text { Southerly }\end{array}$ & Yes & North & 22 & 500 & 0.25 \\
\hline $\begin{array}{l}19 \\
20 \\
\end{array}$ & $\begin{array}{l}20 / 8 / 2003 \\
20 / 8 / 2003 \\
\end{array}$ & Summer & $\begin{array}{l}15: 55 \\
16: 01 \\
\end{array}$ & 4000 & 6.8 & $1-5$ & Yes & $5-10$ & Southeasterly & Yes & $\begin{array}{l}\text { North, } \\
\text { South }\end{array}$ & 42 & 450 & 0.15 \\
\hline 21 & 13/8/2004 & Summer & 17:55 & 4000 & 7.3 & $1-6$ & Yes & $5-10$ & $\begin{array}{l}\text { Southerly, } \\
\text { Southeasterly }\end{array}$ & No & $\begin{array}{l}\text { North, East, } \\
\text { South }\end{array}$ & 47 & 500 & 0.1 \\
\hline $\begin{array}{l}22 \\
23 \\
\end{array}$ & $\begin{array}{l}2 / 9 / 2006 \\
2 / 9 / 2006 \\
\end{array}$ & Autumn & $\begin{array}{l}17: 35 \\
17: 45 \\
\end{array}$ & 5000 & 7.7 & $2-6$ & Yes & 5 & $\begin{array}{l}\text { Southwesterly, } \\
\text { Southerly }\end{array}$ & No & $\begin{array}{l}\text { North, East, } \\
\text { South }\end{array}$ & 47 & 500 & 0.15 \\
\hline $\begin{array}{l}24 \\
25 \\
26 \\
27\end{array}$ & $\begin{array}{l}27 / 3 / 2007 \\
27 / 3 / 2007 \\
27 / / 2007 \\
27 / 3 / 2007\end{array}$ & Spring & $\begin{array}{l}15: 55 \\
16: 05 \\
16: 29 \\
16: 40\end{array}$ & 3000 & 6.2 & $1-8$ & Yes & $12.5-20.5$ & Northwesterly & Yes & North & 27 & 500 & 0.2 \\
\hline 28 & 9/4/2007 & Spring & 19:18 & 2500 & 4.4 & $1-2$ & Yes & 7.5-15 & $\begin{array}{l}\text { Northerly, } \\
\text { Northwesterly }\end{array}$ & Yes & $\begin{array}{c}\text { North, West, } \\
\text { East }\end{array}$ & 30 & 500 & 0.2 \\
\hline $\begin{array}{l}29 \\
30 \\
31 \\
32 \\
33 \\
34\end{array}$ & $\begin{array}{l}1 / 9 / 2007 \\
1 / 9 / 2007 \\
1 / 9 / 2007 \\
1 / 9 / 2007 \\
1 / 9 / 2007 \\
1 / 9 / 2007\end{array}$ & Autumn & $\begin{array}{l}17: 12 \\
17: 14 \\
17: 15 \\
17: 16 \\
17: 17 \\
17: 20\end{array}$ & 5000 & 6.8 & $2-8$ & Yes & 5 & $\begin{array}{l}\text { North, } \\
\text { South }\end{array}$ & No & $\begin{array}{l}\text { North, } \\
\text { South }\end{array}$ & 47 & 500 & 0.15 \\
\hline
\end{tabular}


Table A1. Cont.

\begin{tabular}{|c|c|c|c|c|c|c|c|c|c|c|c|c|c|c|}
\hline S.N. & Date & Season & Local Time & $\begin{array}{c}\text { Planetary } \\
\text { Boundary } \\
\text { Layer Depth } \\
\text { (m) }(900-600 \\
\text { hPa) } \\
\end{array}$ & $\begin{array}{c}\text { Lapse Rate } \\
\left({ }^{\circ} \mathrm{C} / \mathrm{km}\right) \\
(900-600 \\
\mathrm{hPa})\end{array}$ & $\begin{array}{c}\text { Turbulent } \\
\text { Kinetic } \\
\text { Energy } \\
(\mathrm{J} / \mathrm{kg}) \\
(90-600 \\
\text { hPa) }\end{array}$ & $\begin{array}{c}\text { Cold } \\
\text { Trough } \\
(900-600 \\
\text { hPa) }\end{array}$ & $\underset{(\mathrm{m} / \mathrm{s})}{\text { Wind Speed }}$ & $\begin{array}{c}\text { Wind } \\
\text { Direction }\end{array}$ & $\begin{array}{c}\text { Cyclonic Jet } \\
\text { (900-600 } \\
\text { hPa) }\end{array}$ & $\begin{array}{c}\text { Influx of } \\
\text { Vertical } \\
\text { Sensible } \\
\text { Heat from } \\
(900-600 \\
\text { hPa) }\end{array}$ & $\begin{array}{c}\text { Soil } \\
\text { Temperature } \\
(0-10 \mathrm{~cm})^{\circ} \mathrm{C}\end{array}$ & $\begin{array}{c}\text { Soil } \\
\text { Moisture } \\
(0-200 \mathrm{~cm}) \\
\left(\mathrm{kg} / \mathrm{m}^{2)}\right.\end{array}$ & 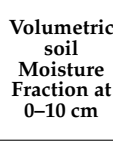 \\
\hline $\begin{array}{l}35 \\
36 \\
\end{array}$ & $\begin{array}{l}16 / 10 / 2007 \\
16 / 10 / 2007 \\
\end{array}$ & Autumn & $\begin{array}{l}12: 55 \\
13: 55 \\
\end{array}$ & 2000 & 5.3 & $1-4$ & Yes & $5-27.5$ & Northwesterly & Yes & $\begin{array}{c}\text { North, } \\
\text { South, East }\end{array}$ & 27 & 500 & 0.1 \\
\hline 37 & $1 / 3 / 2008$ & Spring & 20:55 & 1500 & 3.5 & $1-2$ & Yes & $5-40$ & Northwesterly & Yes & $\begin{array}{l}\text { North, } \\
\text { Southeast }\end{array}$ & 17 & 500 & 0.2 \\
\hline 38 & $30 / 4 / 2008$ & Spring & 4:55 & 1500 & 2.7 & $0.3-1$ & No & $5-20$ & Northwesterly & Yes & $\begin{array}{l}\text { North, } \\
\text { South }\end{array}$ & 18 & 500 & 0.15 \\
\hline 39 & 14/4/2009 & Spring & $16: 24$ & 3500 & 6.6 & $1-12$ & Yes & $\mathrm{NA}$ & $\mathrm{NA}$ & $\mathrm{NA}$ & $\begin{array}{l}\text { North, West, } \\
\text { South, East }\end{array}$ & 32 & 500 & 0.15 \\
\hline $\begin{array}{l}40 \\
41 \\
42 \\
43 \\
44 \\
\end{array}$ & $\begin{array}{l}27 / 10 / 2009 \\
27 / 10 / 2009 \\
27 / 10 / 2009 \\
27 / 10 / 2009 \\
27 / 10 / 2009 \\
\end{array}$ & Autumn & $\begin{array}{l}8: 46 \\
9: 55 \\
10: 35 \\
12: 07 \\
12: 23 \\
\end{array}$ & 2500 & 3.1 & $1-2.5$ & Yes & $5-27.5$ & Northwesterly & Yes & North, West, & 15 & 500 & 0.15 \\
\hline 45 & $16 / 2 / 2011$ & Winter & 12:28 & 2000 & 4.6 & $1-2$ & No & $10-32.5$ & Southwesterly & Yes & North & 12 & 600 & 0.25 \\
\hline 46 & 23/9/2011 & Autumn & 16:55 & 6000 & 7.5 & $4-6$ & Yes & $5-12.5$ & $\begin{array}{l}\text { Southeasterly, } \\
\text { Southwesterly }\end{array}$ & No & North & 37 & 500 & 0.15 \\
\hline
\end{tabular}




\section{References}

1. Goudie, A.S.; Middleton, N.J. Desert Dust in Global System; Springer: Berlin, Germany, 2006.

2. Mahowald, N.M.; Bryant, R.G.; Corral, J.D.; Steinberger, L. Ephemeral lakes and desert dust sources. Geophys. Res. Lett. 2003, 30, 1074-1078. [CrossRef]

3. Sokolik, I.N.; Toon, O.B. Incorporation of mineralogical composition into models of the radiative properties of mineral aerosol from UV to IR wavelengths. J. Geophys. Res. 1999, 104, 9423-9444. [CrossRef]

4. Tegen, I.; Fung, I. Modeling of mineral dust in the atmosphere: Sources, transport, and surface modification. J. Geophys. Res. 1994, 99, 22897-22914. [CrossRef]

5. Huang, J.; Fu, Q.; Su, J.; Tang, Q.; Minnis, P.; Hu, Y.; Zhao, Q. Taklimakan dust aerosol radiative heating derived from CALIPSO observations using the Fu-Liou radiation model with CERES constrains. Atmos. Chem. Phys. 2009, 9, 4011-4021. [CrossRef]

6. Seinfeld, J.H.; Carmichael, G.R.; Arimoto, R.; Conant, W.C.; Brechrel, F.J.; Bates, T.S.; Cahill, T.A.; Clarke, A.D.; Doherty, S.J.; Flatau, P.J.; et al. Regional climatic and atmospheric chemical effects of Asian dust and pollution. Bull. Am. Meteorol. Soc. 2004, 85, 367-380. [CrossRef]

7. Shao, Y.; Wyroll, K.-H.; Chappel, A.; Huang, A.; Lin, Z.; McTanish, G.H.; Mikami, M.; Tanaka, T.Y.; Wang, X.; Yoon, S. Dust cycle: An emerging core theme in Earth system science. Aeolian Res. 2011, 2, 181-204. [CrossRef]

8. Tegen, I. Modeling the mineral dust aerosol cycle in the climate system. Quat. Sci. Rev. 2003, 22, 1821-1834. [CrossRef]

9. Appel, B.R.; Tokiwa, Y.; Hsu, J.; Kothny, E.I.; Hahn, E. Visibility as related to atmospheric aerosol constituents. Atmos. Environ. 1985, 19, 1525-1534. [CrossRef]

10. Chan, Y.C.; Simpson, R.W.; Mctainsh, G.H.; Vowles, P.D.; Cohen, D.D.; Bailey, G.M. Source apportionment of visibility degradation problems in Brisbane (Australia)—Using the multiple linear regression techniques. Atmos. Environ. 1999, 33, 3237-3250. [CrossRef]

11. Environmental Effects of Particulate Matter (EEPA). Available online: https://www.princeton.edu/step/ conferences-reports/reports/ch5.pdf (accessed on 1 August 2016 ).

12. Elias, T.; Haeffelin, M.; Drobinski, P.; Gomes, L.; Rangognio, J.; Bergot, T.; Chazette, P.; Raut, J.C.; Colomb, M. Particulate contribution to extinction of visible radiation: pollution, haze and fog. Atmos. Res. 2009, 92, 443-454. [CrossRef]

13. Griffin, D.W.; Garrisin, V.H.; Herman, J.R.; Shinn, E.A. African desert dust in the Caribbean atmosphere. Aerobilogia 2001, 173, 203-213. [CrossRef]

14. Korenyi-Both, A.L.; Kornyi-Both, A.L.; Molnar, A.C.; Fidelus-Gort, R. Al Eskan disease: Desert Storm pneumonitis. Mil. Med. 1992, 157, 452-462. [PubMed]

15. Nouh, M.S. Is the desert lung syndrome (nonoccupational dust pneumoconiosis) a variant of pulmonary alveolar microlithiasis? Respiration 1989, 55, 122-126. [CrossRef] [PubMed]

16. Venkatesh, M.V.; Joshi, K.R.; Harjai, S.C.; Ramdeo, I.N. Aspergillosis in desert locust (Schistocerka gregaria Forsk). Mycopathologia 1975, 57, 135-138. [CrossRef] [PubMed]

17. Williams, P.L.; Sable, D.L.; Mendez, P.; Smyth, L.T. Symptomatic coccidioidomycosis following a severe natural dust storm. An outbreak at the Naval Air Station, Lemoore, Calif. Chest 1979, 76, 566-570. [CrossRef] [PubMed]

18. Okin, G.S.; Reheis, M. An Enso predictor of dust emission in the southwestern United States. Geophys. Res. Lett. 2002, 29, 46-1-46-3. [CrossRef]

19. Reheis, M.C.; Urban, F.E. Regional and climatic controls on seasonal dust deposition in the southwestern U.S. Aeolian Res. 2011, 3, 3-21. [CrossRef]

20. Pye, K. Aeolian Dust and Dust Deposits; Academic Press, Inc.: Orlando, FL, USA, 1987.

21. Reheis, M.C.; Kihl, R. Dust deposition in southern Nevada and California, 1984-1989: Relations to climate, source area, and source lithology. J. Geophys. Res. 1995, 100, 8893-8918. [CrossRef]

22. Okin, G.S.; Gillette, D.A.; Herrick, J.E. Multi scale controls on and consequences of Aeolian process in landscape change in arid and semi-arid environments. J. Arid Environ. 2006, 65, 253-275. [CrossRef]

23. Nickling, W.G.; Brazel, A.J. Temporal and spatial characteristics of Arizona dust events (1965-1980). J. Climatol. 1984, 4, 645-660. [CrossRef] 
24. Belnap, J.; Reynolds, R.L.; Reheis, M.C.; Philips, S.L.; Urban, F.E.; Goldstein, H.I. Sediment losses and gains across a gradient of livestock grazing and plant invasion in cool, semi-arid grassland, Colorado Plateau, USA. Aeolian Res. 2009, 1, 27-43. [CrossRef]

25. Field, J.P.; Belnap, J.; Breshears, D.D.; Neff, J.C.; Okin, G.S.; Whicker, J.J.; Painter, T.H.; Ravi, S.; Reheis, M.C.; Reynolds, R.L. The ecology of dust. Front. Ecol. Environ. 2009, 8, 423-430. [CrossRef]

26. Reheis, M.C.; Budahn, J.R.; Lamothe, P.J.; Reynolds, R.L. Compositions of modern dust and surface sediments in the Desert Southwest, United States. J. Geophys. Res. 2009, 114. [CrossRef]

27. Mitchell, J.M., Jr.; Stockton, C.W.; Meko, D.M. Evidence of a 22-year rhythm of drought in the western United States related to the hale solar cycle since the 17th Century. In Solar-Terrestrial Influences on Weather and Climate; McCormac, B.M., Seliga, T.A., Reidel, D., Eds.; Springer: Dordrecht, The Netherlands, 1979; pp. 125-143.

28. Reheis, M.C. A 16-year record of aeolian dust in Southern Nevada and California, USA: Controls on dust generation and accumulation. J. Arid Environ. 2006, 6, 487-520. [CrossRef]

29. Neff, J.C.; Ballantine, A.P.; farmer, G.L.; Mahowald, N.M.; Conroy, J.L.; Landry, C.C.; Overpeck, J.T.; Painter, T.H.; Lawrence, C.R.; Reynolds, R.L. Increasing eolian dust deposition in the western United States lined to human activity. Nat. Geosci. 2008, 1, 189-195. [CrossRef]

30. Reynolds, R.L.; Mordecai, J.S.; Rosenbaum, J.G.; Ketterer, M.E.; Walsh, M.K.; Moser, K.A. Compositional changes in sediments of subalpine lakes, Uinta dust inputs. J. Paleolimnol. 2009, 44, 161-175. [CrossRef]

31. Diffenbaugh, N.S.; Giorgi, F.; Pal, J.S. Climate change hotspots in the United States. Geophys. Res. Lett. 2008, 35. [CrossRef]

32. McAfee, S.A.; Russel, J.L. Northern Annular Mode impact on spring climate in the western United States. Geophys. Res. Lett. 2008, 35. [CrossRef]

33. Sweeney, M.R.; McDonald, E.V.; Etymezian, V. Quantifying dust emissions from desert landforms, eastern Mojave Desert, USA. Geomorphology 2011, 135, 21-34. [CrossRef]

34. Tong, D.Q.; Dan, M.; Wang, T.; Lee, P. Long-term dust climatology in the western United States reconstructed from routine aerosol ground monitoring. Atmos. Chem. Phys. 2012, 12, 5189-5205. [CrossRef]

35. Natural Resource Conservation Service. Appendix D: Detailed affected environment data. In Emergency Watershed Protection Program-Draft Programmatic Environmental Impact Statement; US Department of Agriculture, Natural Resource Conservation Service: Washington, DC, USA, 1999; p. 49.

36. Changery, M.J. A Dust Climatology of the Western United States; National Climatic Data Center, NUREG/CR-3211, RB; National Oceanic and Atmospheric Administration: Asheville, NC, USA, 1983.

37. Sharatt, B.S.; Lauer, D. Particulate Matter Concentration and Air Quality Affected by Windblown Dust in the Columbia Plateau. J. Environ. Qual. 2006, 35, 2011-2016. [CrossRef] [PubMed]

38. Edwards Air Force Base (EAFB) (1997-2011). Available online: http://www.wunderground.com/history/ airport/KEDW /2012/05/30/DailyHistory.html (accessed on 13 October 2013).

39. Orgill, M.M.; Sehmel, G.A. Frequency and diurnal variation of dust storms in the contiguous USA. Atmos. Environ. 1976, 10, 813-825. [CrossRef]

40. Mesinger, F.; Dimego, G.; Kalnay, E.; Kenneth, M.; Shafran, P.C.; Ebisuzaki, W.; Jovic, D.; Woollen, J.; Rogers, E.; Berbery, E.H.; et al. North American Regional Reanalysis. Bull. Am. Meteor. Soc. 2006, 87, 343-360. [CrossRef]

41. Brazel, A.J.; Nickling, W.G. The relationship of weather types to dust storm generation in Arizona (1965-1980). J. Climatol. 1986, 6, 255-275. [CrossRef]

42. Hagen, L.J.; Woodruff, N.P. Air Pollution from dust storms in the Great Plains. Atmos. Environ. 1973, 7, 323-332. [CrossRef]

43. Chen, Y.-S.; Sheen, P.-C.; Chen, E.-R.; Liu, Y.-K.; Wu, T.-N.; Yang, C.-Y. Effects of Asian dust storm events on daily mortality in Taipei, Taiwan. Environ. Res. 2004, 95, 151-155. [CrossRef] [PubMed]

44. Novlan, D.J.; Hardiman, M.; Gill, T.E. Synoptic Climatology of Blowing Dust Events in El Paso, Texas from 1932-2005. In Proceedings of the 14th Symposium on Meteorological Observations and Instrumentation and the 16th Conference on Applied Climatology, Asheville, NC, USA, 14-15 January 2007.

45. Yang, C.-Y.; Tsai, S.-S.; Chang, C.-C.; Ho, S.-C. Effects of Asian Dust Storm Events on Daily Admissions for Asthma in Taipei, Taiwan. Inhal. Toxicol. 2005, 17, 817-821. [CrossRef] [PubMed]

46. Okin, G.S.; Murray, B.; Schlesinger, W.H. Degradation of sandy arid shrub land environments: Observations, process modeling, and management implications. J. Arid Environ. 2001, 47, 123-144. [CrossRef] 
47. Hall, F.F., Jr. Visibility reductions from soil dust in the western US. Atmos. Environ. 1981, 15, $1929-1933$. [CrossRef]

48. Kaplan, M.L.; Vellore, R.K.; Lewis, J.M.; Underwood, S.J.; Pauley, P.M.; Martin, J.E.; Krishnan, R. Re-examination of the I-5 dust storm. J. Geophys. Res. Atmos. 2013, 118, 627-642. [CrossRef]

49. Danielsen, E.F. Stratospheric-tropospheric exchange of radioactivity, ozone, and potential vorticity. J. Atmos. Sci. 1968, 25, 502-518. [CrossRef]

50. Danielsen, E.F. The Generation and Triggering of Severe Convective Storms by Large-Scale Motions. In Proceedings of the Severe Environmental Storms and Mesoscale Experiment (SESAME), Boulder, CO, USA, 4-6 September 1974.

51. Glassby, G.P. The influence of Aeolian transport of dust particles on marine sedimentation in the South-west Pacific. J. R. Soc. N. Z. 1971, 1, 3-4. [CrossRef]

52. Bagnold, R.A. The Physics of Blown Sand and Desert Dunes; Methuen and Co., Ltd.: London, UK, 1941.

53. Shimzu, A.; Sugimoto, N.; Matsui, I.; Arao, K.; Uno, I.; Murayama, T.; Kagawa, N.; Aoki, K.; Uchiyama, A.; Yamazaki, A. Continuous observations of Asian dust and other aerosols by polarization lidars in China and Japan during ACE-Asia. J. Geophys. Lett. 2004, 109. [CrossRef]

54. Karyampudi, V.M.; Kaplan, M.L.; Koch, S.E.; Zamora, R. The influence of the Rocky Mountains in the 13-14 April 1986 severe weather outbreak. Part I: Mesoscale lee cyclogenesis and its relationship to severe weather and dust storms. Mon. Weather Rev. 1995, 123, 1394-1422. [CrossRef]

55. Lewis, J.M.; Kaplan, M.L.; Vellore, R.; Rabin, R.M.; Hallett, J.; Cohn, S.A. Dust storm over the Black Rock Desert: Larger-scale dynamic signatures. J. Geophys. Res. 2011, 116. [CrossRef]

56. Goudie, A.S.; Middleton, N.J. The changing frequency of dust storms through time. Clim. Chang. 1992, 20, 197-225. [CrossRef]

57. Lee, J.A.; Wigner, K.A.; Gregory, J.M. Drought, wind, and blowing dust on the southern High Plains of the United States. Phys. Geog. 1993, 14, 56-67.

(C) 2017 by the authors. Licensee MDPI, Basel, Switzerland. This article is an open access article distributed under the terms and conditions of the Creative Commons Attribution (CC BY) license (http:/ / creativecommons.org/licenses/by/4.0/). 